\title{
IAMJ
}

INTERNATIONAL AYURVEDIC MEDICAL JOURNAL

\section{A REVIEW ON PANDEMIC COVID-19 AND ITS MANAGEMENT APPROACH WITH AYURVEDA}

\author{
Sagar Ambadas Avhale', Pritilata Sagar Avhale ${ }^{2}$ \\ ${ }^{1}$ MS (Stree Roga \& Prasuti Tantra), Assistant Professor, Dept of Stree Roga \& Prasuti Tantra, \\ SRC Ayurveda College, Chikhali, Maharashtra - 443201, India \\ ${ }^{2}$ MD (Kaumarbhrutya) Sch., SMBT Ayurveda College, Igatpuri, Nashik, Maharashtra, India
}

Corresponding Author: sagaravhale@gmail.com

\section{https://doi.org/10.46607/iamj3208112020}

(Published online: November 2020)

Open Access

(C) International Ayurvedic Medical Journal, India 2020

Article Received: 17/11/2020 - Peer Reviewed: 18/11/2020 - Accepted for Publication: 20/11/2020

\section{A) Check for updates}

\begin{abstract}
Globally it is a high research is currently going on and need of suitable approach for the best treatment for corona virus 2 (SARS CoV 2). It is a pandemic and highly contagious entire mankind is suffering. Coronaviruses are single stranded positive-sense RNA viruses that possess large viral RNA genomes. Sequence analysis showed that the 2019-nCoV possesses a typical genome structure of coronavirus and belongs to the cluster of beta corona viruses. In Covid 19 outbreak, enhancing one own's defence system (immunity) plays an important role in maintaining best health. According to Ayurveda, without the vitiation of any of three Dosha, no disease can occur, so balance of three dosha should be maintain for good hygiene. As Ayurveda described several immunity booster herbal drugs. Ayurved envisages the root of cause for any illnesses. Ayurveda is likely to provide evidence-based medicine for preventive health care and enhance the self-immunity. Many researchers perhaps the whole world is looking for a effective drug or safe and effective vaccine for covid-19 which should be cost effective, easily available. A better Prevention through Ayurveda approach can be achieved in this pandemic of covid-19., as globally it is now accepted therapy for the prevention of covid and also used as immunity booster.
\end{abstract}

Keyword: immunity, corona virus, covid-19, dosha, defence system 


\section{INTRODUCTION}

In December 2019, an outbreak of COVID-19, caused by a novel severe acute respiratory syndrome coronavirus 2 (SARS-CoV-2) infection attacking mainly on the immune system of a body, occurred in Wuhan City, Hubei Province, China. Recently corona virus infection is caused due a novel corona virus 2 (SARS CoV 2), it is a pandemic and highly contagious. Coronaviruses are single stranded positive-sense RNA viruses that possess large viral RNA genomes. ${ }^{2}$ Sequence analysis showed that the 2019-nCoV possesses a typical genome structure of coronavirus and belongs to the cluster of beta corona viruses. related to Severe Acute Respiratory Syndrome (SARS) from 2002-2004 and Middle East Respiratory Syndrome (MERS) in 2012. ${ }^{3}$ On January 30, the WHO announced a Public Health Emergency of International Concern (PHEIC) for the 2019-nCoV outbreak. The most common symptoms at onset of COVID-19 illness are fever, cough, and fatigue, while other symptoms include sputum production, headache, haemoptysis, diarrhoea, dyspnoea, and lymphopenia. ${ }^{4}$

In the Covid 19 outbreak, whole mankind globally is suffering from this disorder. Enhancing one own's defence system (immunity) plays an important role in maintaining best health. We all know that the prevention is better than cure any disease. As per Ayurveda, pandemic diseases are those disease which spread from one person to other. As far as there is no medicine for COVID-19 as of now, various efforts are going for the preventive measures which boost our immunity.

Charak Samhita - Vimana Sthana - Chapter III is dedicated to "Jan-Padodwansa", it explains that these Pandemics are caused by imbalance of dosha's or we can say Environmental Degradation of Air ( Vayu) Water (Jala) Country (Desha) and Time (Kala) can be a cause for various epidemic diseases at various places. In Ayurveda it is considered as 'Agantuj Vikar' and its types are Adhidaivik, Daivabalpravrutta and Aupsargic vikar. ${ }^{5}$ The concept of treatment in Ayurveda for any sickness based on body humours i.e. on Tridoshas (Vata, Pitta and Kapha). In order to balance these three dosha, it is necessary to optimize the Ojas (immunity level) by correcting the Agni (metabolism), which further enhancing the Dhatu Sarata (quality of body tissue at different level). ${ }^{6}$

Acharya Sushruta said that, without the vitiation of any of three Dosha, no disease can occur so it is advised to treat and make balance of three dosha should be maintain for good hygiene. The Rasayana drug is providing passive immunity (yuktikrita-bala). As postulated, Vyadhikshamatwa (immunity), which depends on the ojas, provokes the strength of disorders and prevent it. ${ }^{7}$ It is observed that mortality was more among older people, probably because of the poor immunity and any other illnesses leads to faster progress of COVID-19. Rasayana dravyas (immuno modulators drugs) can be used for health promotion, immune-modulation, prevention and decrease disease burden from COVID-19. Hence it is more important to enhance our immune system to fight against this condition.

\section{Ayurveda approach towards COVID-19:8,9}

In Ayurveda, there are several immunity booster herbal drugs, Ayurved envisages the root of cause for any illnesses. Ayurveda's extensive knowledge based on preventive care, derives from the Ayurveda also give specifies guideline about maintaining hygiene through concepts of "Dinacharya" daily regimes and "Ritucharya" seasonal regimes to maintain healthy life.

Ministry of AYUSH and AYUSH task force has advised the Covid-19 treatment as following. ${ }^{10,11}$

Asymptomatic Patients and positive for COVID-19 For Jwar,

1. Guduchi Ghana Vati,

2. Guduchi, Pippalimoola, Sounth equal part Kashaya

3. Tab AYUSH 64

4. Mrityunjay Rasa 25-500mg tds with Madhu

\section{For Dry Cough}

1. Vasavaleha, Drakshavaleha, Kaphakuthar rasa $250 \mathrm{mg}$ tds

2. Sitopaladi churna $2 \mathrm{gm}+$ Godanti Bhasma $250 \mathrm{mg}$

3. Sitopaladi churna $2 \mathrm{gm}+$ Praval bhasma $250 \mathrm{mg}+$ Guduchi satva 250mg

Immunity Promoting General medicine: -

1. Chyavanprash $10 \mathrm{gm}$ in the morning and evening with milk. 
2. Herbal tea / decoction (Kadha) prepared from Tulsi (Basil), Dalchini (Cinnamon), Kalimirch (Black pepper), Shunthi (Dry Ginger) and Munakka (Raisin) - once or twice a day.

3. Golden Milk- Half teaspoon Haldi (turmeric) powder in $150 \mathrm{ml}$ hot milk - once or twice a day.

4. Nasal application (Nasya) - Apply sesame oil and coconut oil or Ghee in both the nostrils (Pratimarsha Nasya) in morning and evening.

General measures: As Drinking warm water on daily basis is very good for digestion and also for immunity, gargling with warm water make help in removing kapha, whenever you go outside home and come back, that time it is very useful, it reduces the chances of infection. Pouring 2- 2 drops of almond oil, Narikel oil or ghee in nasal sinuses is helpful, hyperactivation of the brain comes as a major reason for compromised immunity. Pranayaam, Yogasana, Meditation and Breathing Exercises also can be practiced for maintaining physical strength as well as immunity. Similarly keeping distance from any person and hand washing practice and use of mask continuously also prevent covid-19.

\section{DISCUSSION}

Initially in poorva rupavastha, vitiated Vata Pitta produces fever, myalgia, dry cough, anorexia like complaints in patients. Covid-19 is disease of Vata Pitta predominant but doshadushyasammurcchana takes place in Kapha sthana. Vitiated Vata Pitta depleted the shleshma and shleshma sthana. Vitiated Vata Pitta by its ruksha and ushna guna makes shleshma sthana (Nose, Mouth, Eyes, Urah etc.) ruksha and durbala. When pathology exceeds Vata-Pitta doshas depleted Kapha dosha and by virtue of its ruksha and ushna guna shleshma sthana (Nose, Mouth, Eyes, Urah etc.) becomes ruksha and durbala. It results into affection of these sthana by Vata Pitta, which results into development of symptoms. Lower respiratory tract infection and later on when Dhatupakavastha takes place and then symptoms of Pneumonia appear. At this stage all three doshas are involved in samprapti leading to sannipatavastha and later on respiratory failure and multi organ failure develops, when marmasthanas get involved. Till date, there is no vaccine or perfect treatment available for COVID-19 pandemic. At present, treatment provided to the affected individuals are mainly symptom based, and the seriously ill individuals are provided with ventilator support. Current estimated mortality of COVID-19 for overall infected population is $0.25-3.0 \%$ whereas it increases to $>14 \%$ among elderly (over 80 years). ${ }^{12}$ As per recommendation, many countries are using Hydroxychloroquine(HCQ) and Azithromycin (AZD) as a treatment of COVID-19. It is also proved that there are several side effects of HCQ on the heart, kidney and gastro-intestinal tract. Without proper scientific evidence and alternative choice, the whole world is using this protocol. ${ }^{13}$ Some specialists are advising to use reserved HIV treatment drugs Lopinavir $200 \mathrm{mg}$ and Ritonavir $50 \mathrm{mg}$ in second option which are highly toxic as compared to HCQ and AZD. The whole world is looking for a drug or vaccine which is highly effective, cost effective, easily available with less toxic. ${ }^{14}$

\section{CONCLUSION}

Ayurveda is hope in future for such pandemic as Ayurveda science potential possibilities for both for prevention and treatment of COVID-19. The effective management of covid-19 would be helpful in generating trustworthy evidence. Ayurveda will be hope for comprehensive management for addressing critical challenge in India. Ayurveda is likely to provide evidencebased medicine for preventive health care and enhance the self-immunity and keep away corona virus only with AYUSH system.

\section{REFERENCES}

1. Xiang, Y.-T., Li, W., Zhang, Q., Jin, Y., Rao, W.-W., Zeng, L.-N., Lok, G. K. I., Chow, I. H. I., Cheung, T., Hall, B. J. 2020. Timely research papers about COVID19 in China. The Lancet, 395(10225):684-685.

2. World Health Organization (WHO). 8th May. 2020. Current Outbreak on Coronavirus (COVID-19) Disease. https://www.who.int/healthtopics/coronavirus\#tab=tab[cited on 12.10.2020]

3. Y., W, R., Tsoi, S., Lo, H. W., K, S., Chan, F., Poon, K. H., K, V., Chan, M., Ip, W. M., Cai, J. D., Cheng, J. P., Chen, V. C.-C., Yuen, H., Y, K. 2020. A familial cluster 
of pneumonia associated with the 2019 novel coronavirus indicating person-to person transmission: a study of a family cluster. The Lancet, 395(10223):3015430163.5

4. Rajput DS, Evolution, Ayurveda, immunity, and preventive aspects for emerging infectious diseases such as COVID-19. Int. J. Res. Pharm. Sci., 2020, 11(SPL)(1), 86-93.

[DOI:

https://doi.org/10.26452/ijrps.v11iSPL1.2227 ]

5. Acharya YT. Charaka Samhita of Agnivesha with 'Ayurveda-Dipika' commentary by Chakrapanidatta, Repr. ed. Varanasi. Chaukhamba Surbharati Prakashan. 2000. Sutrasthana, p.76.

6. Nesari TM. Ayurveda: The promising shelter for the mankind in the wake of COVID-19 pandemic. J Ayurveda Case Rep 2020; 3:1-3. [DOI: 10.4103/JACR.JACR_18_20]

7. Acharya YT. Charaka Samhita of Agnivesha with Ayurveda-Deepika Commentary by Chakrarapanidatta, edited by Dr. Brahmanand Tripathi, Varanasi, Choukhambha Surbharati Prakashan, Reprinted 2011, Vimana sthana chapter 3, verse 13-18, Pg. 241.

8. Barge SS, Shashilekha HK, Textbook of Swasthvritta. 1st ed. Reprint, Chaukhambha publications, New Delhi; 2018. Pg. 415-419, 508-5-10.

9. Amitava Acharyya. Prospect of Ayurveda System of Medicine in recent Covid-19 Pandemic in India. IJATM.2020;2(2):26-29.

10. Rastogi S, Pandey DN, Singh RH. COVID-19 pandemic: A pragmatic plan for ayurveda intervention [published online ahead of print, 2020 Apr 23]. J Ayurveda Integr Med. 2020; S0975-9476(20)30019-X. doi:10.1016/j.jaim.2020.04.002

11. GUIDELINES for AYURVEDA PRACTITIONERS for COVID 19, MINISTRY OF AYUSH, AYUSH BHAWAN, NEW DELHI - 110023. https://www.ayush.gov.in/docs/ayurveda.pdf

12. Chaturvedi S, Kumar N, Tillu G, Deshpande S, Patwardhan B. AYUSH, modern medicine and the Covid19 pandemic. Indian J Med Ethics Published online on May 13, 2020. DOI:10.20529/IJME.2020.058

13. Wu, C., Liu, Y., Yang, Y., Zhang, P., Zhong, W., Wang, Y., Wang, Q., Xu, Y., Li, M., Li, X., 2020b. Analysis of therapeutic targets for SARS-CoV-2 and discovery of potential drugs by computational methods. Acta Pharm. Sin. B [DOI: 10.1016/j. apsb.2020.02.008]

14. Ali, O.M.L. Alharbi. COVID-19: Disease, management, treatment, and social impact. Science of the Total
Environment $728 \quad(2020) \quad 138861 \quad$ [DOI:

https://doi.org/10.1016/j.scitotenv.2020.138861]

\section{Source of Support: Nil \\ Conflict of Interest: None Declared}

How to cite this URL: Sagar Ambadas Avhale \& Pritilata Sagar Avhale: A Review On Pandemic Covid-19 And Its Management Approach With Ayurveda. International Ayurvedic Medical Journal \{online\} 2020 \{cited November, $2020\}$ Available from: http://www.iamj.in/posts/images/upload/5157 5160.pdf 